\title{
Pengaruh Perencanaan Sumber Daya Manusia, Rekrutmen dan Penempatan Terhadap Kinerja Karyawan Kantor Perwakilan Bank Indonesia Provinsi Bengkulu
}

\author{
Heru Saputra \\ Universitas Dehasen Bengkulu \\ Ahmad Soleh * \\ Universitas Dehasen Bengkulu \\ Ida Ayu Made Er Meytha Gayatri \\ Universitas Dehasen Bengkulu \\ Email:*ahmadsolehse81@yahoo.co.id
}

\begin{abstract}
Abstrak
Peningkatan kinerja karyawan dapat dilakukan melalui perencanaan sumber daya manusia, rekrutmen serta penempatan karyawan yang sesuai dengan pendidikan dan keterampilan. Tujuan penelitian ini adalah untuk menganalisis pengaruh perencanaan sumber daya manusia, rekrutmen dan penempatan terhadap kinerja karyawan Kantor Perwakilan Bank Indonesia Provinsi Bengkulu. Metode pengumpulan data dengan membagikan kuesioner kepada 48 karyawan. Analisis data yang digunakan adalah analisis kuantitatif, dengan metode regresi linier berganda, uji determinasi, uji t dan uji F. Hasil penelitian menunjukkan bahwa perencanaan sumber daya manusia, rekrutmen dan penempatan berpengaruh positif dan signifikan secara parsial dan simultan terhadap kinerja karyawan Kantor Perwakilan Bank Indonesia Provinsi Bengkulu.
\end{abstract}

Keywords: Perencanaan SDM, rekrutmen, penempatan, kinerja

\section{Pendahuluan}

Sumber daya manusia merupakan salah satu faktor penting dalam suatu organisasi atau perusahaan untuk mencapai tujuan dan sasarannya. Sumber daya manusia merupakan faktor penentu berhasil atau tidaknya dalam pencapaian tujuan. Sumber daya manusia yang dimaksud disini adalah karyawan. Karyawan memiliki andil sebagai perencana, pelaksana dan pengendali yang selalu berperan aktif dalam mewujudkan tujuan organisasi atau perusahaan. Peranan sumber daya manusia menjadi semakin penting jika dikaitkan dengan perkembangan global yang penuh dengan persaingan diantara organisasi atau perusahaan. Salah satu cara yang dilakukan dalam menghadapi persaingan yaitu dengan memberdayakan dan menggali seluruh potensi sumber daya manusia yang dimilikinya secara maksimal.

Mengacu kondisi tersebut, maka suatu organisasi atau perusahaan perlu meningkatkan perhatiannya terhadap kualitas karyawannya, baik perhatian dari kualitas pengetahuan dan keterampilan, karir maupun kesejahteraan sehingga dapat meningkatkan prestasi dan motivasi karyawan untuk memberikan seluruh kemampuannya dalam pencapaian tujuan. Menyadari begitu pentingnya pengelolaan sumber daya manusia dalam mencapai tujuan organisasi atau perusahaan, maka pimpinan perlu meningkatkan perhatian terhadap karyawan dalam upaya meningkatkan kinerjanya. Kinerja karyawan sangat menentukan kemajuan suatu perusahaan. Hal ini menjadi kewajiban seorang pimpinan untuk dapat menciptakan suasana yang dapat mendukung terciptanya kinerja yang tinggi dari karyawan. Kinerja setiap karyawan dapat dipengaruhi oleh penempatan karyawan pada posisi yang tepat dan pemberian pelatihan 
terhadap karyawan.

Perencanaan sumber daya manusia dirancang untuk menjamin bahwa kebutuhan organisasi atau perusahaan mengenai kebutuhan pegawai akan terpenuhi secara tepat. Perencanaan sumber daya manusia merupakan fungsi yang pertama kali harus dilaksanakan dalam organisasi. Manajemen sumber daya manusia yang berbasis kompetensi merupakan salah satu konsep manajemen yang mengaitkan aktivitas sumber daya manusia di dalam organisasi dengan kompetensi dasar yang akan diunggulkan. Salah satu yang harus diperhatikan dalam mengelola sumber daya manusia adalah rekrutmen. Dalam proses rekrutmen diperlukan adanya proses seleksi yang efektif, hal ini dilakukan untuk melakukan pemerataan karyawan sehingga kekuatan sumber daya manusia yang dimiliki menjadi lebih seimbang. Proses rekrtumen menjadi aspek penting bagi suatu perusahaan. Bohlander (2010) menyebutkan bahwa terdapat beberapa orang yang bertanggung jawab dalam melakukan proses rekrutmen. Bagi perusahaan kecil biasanya rekrtumen dilakukan oleh seorang HR secara generalis, namun bagi perusahaan yang tidak memiliki manajer $\mathrm{HR}$, maka seorang manager umum atau supervisor dapat melakukan proses rekrutmen sendiri.

Hal lain yang perlu diperhatikan perusahaan dalam mempengaruhi kinerja karyawan adalah penempatan kerja karyawan. Penempatan adalah menempatkan posisi seseorang ke posisi pekerjaan yang tepat, seberapa baik seorang karyawan cocok dengan pekerjaannya akan mempengaruhi jumlah dan kualitas pekerjaan. Penempatan sumber daya manusia yang tepat merupakan cara mengoptimalkan pengetahuan, keterampilan dan sikap menuju kinerja bagi sumber daya manusia itu sendiri, hal ini sangat penting karena bagi suatu perusahaan penempatan pegawai pada posisi yang tepat merupakan suatu hal yang erat hubungannya dengan kinerja pegawai dalam memberikan manfaat yang besar bagi perusahaan. Perusahaan sangat membutuhkan sumber daya manusia yang kompeten dan berkualitas, terutama memelihara kualitas kehidupan kerja dan membina tenaga kerja agar bersedia memberikan kontribusinya secara optimal untuk mencapai tujuan perusahaan. Penempatan karyawan dalam posisi jabatan yang tepat akan membantu perusahaan untuk mendapatkan hasil kerja yang optimal dan mencapai tujuan yang diharapkan. Sebagaimana pernyataan Hasibuan (2017) bahwa penempatan harus didasarkan pada deskripsi pekerjaan dan spesifikasi pekerjaan yang telah ditentukan serta berpedoman kepada prinsip orang yang tepat ditempat yang tepat dan orang yang tepat di belakang pekerjan.

Kinerja karyawan merupakan suatu hal yang sangat penting dalam upaya perusahaan untuk mencapai tujuan (Rivai, 2013). Oleh karena itu, pihak manajemen perusahaan hurus berusaha mendorong karyawan untuk bekerja dengan baik sehingga dapat mencapai prestasi yang terbaik. Untuk menciptakan kinerja karyawan tentu saja ada beberapa hal yang harus diperhatikan oleh perusahaan, seperti penempatan dan pelatihan kerja karyawan. Seorang karyawan yang ditempatkan sesuai dengan keahlian dan keterampilan yang dimilikinya akan memiliki prestasi yang jauh lebih baik dari pada karyawan yang menempati posisi yang tidak sesuai dengan latar belakang pendidikan dan keahlian yang dimilikinya. Selain itu, peningkatan kinerja dapat ditunjang dengan pemberian pelatihan terhadap karyawan.

Kantor Perwakilan Bank Indonesia Provinsi Bengkulu merupakan lembaga tinggi negara yang mengatur keuangan negara. Dalam pelaksanaan tugas dan tanggungjawab dari para karyawannya dituntut para karyawan memiliki kinerja yang tinggi sehingga karyawan mampu melaksanakan tugas dan tanggungjawabnya sesuai dengan tupoksi yang telah ditetapkan. Pada Kantor Perwakilan Bank Indonesia Provinsi Bengkulu memiliki karyawan tetap dan karyawan outsorsing yang terbagi menjadi beberapa unit kerja atau divisi, yang mana karyawan satu dengan lainnya memiliki pengetahuan, keterampilan dan sikap yang berbedabeda, sehingga peran penempatan kerja dan pelatihan karyawan yang tepat dan sesuai sangat vital untuk mengoptimalkan kinerja. Sebelum penerimaan karyawan juga dilakukan rekrutmen 
dengan cara mengumumkan pembukaan lowongan dan diadakan seleksi atau tes untuk rekrutmen karyawan baru.

Berdasarkan fenomena yang ada, ditemukan bahwa masih terdapat karyawan dengan kinerja yang kurang baik. Hal tersebut terlihat dari masih adanya penempatan karyawan yang tidak sesuai dengan keahlian dan latar belakang pendidikannya, hal ini akan menyebabkan rendahnya kinerja karyawan karena karyawan merasa bingung dengan pekerjaan yang dibebankan kepadanya. Seperti lulusan Sarjana Komputer ditempatkan pada bagian pengiriman barang dan paket, Sarjana Ekonomi ditempatkan pada bagian pelayanan. Hal seperti ini dapat menyebabkan menurunnya tingkat kinerja karyawan. Hasil pra penelitian juga menunjukan bahwa faktor lain yang dianggap mempengaruhi kinerja karyawan adalah rekrutmen. Diduga masih terdapat kecurigaan atas proses seleksi penerimaan karyawan tetap.

Studi literatur menunjukkan bahwa terdapat beberapa penelitian sebelumnya yang menemukan perencanaan sumber daya manusia memiliki pengaruh positif dan signifikan terhadap kinerja karyawan (Fitria, 2017; Haqiqi, 2017; Saputra, dkk. 2020). Hafni dan Husni (2016) menemukan hasil yang berbeda, bahwa perencanaan SDM memiliki pengaruh positif namun tidak signifikan terhadap kinerja karyawan. Demikian halnya dengan hasil penelitian yang dilakukan oleh Rafikah (2020), menemukan bahwa perencanaan SDM tidak memiliki pengaruh terhadap kinerja karyawan. Selanjutnya studi literatur tentang rekrutmen ditemukan memiliki pengaruh positif dan signifikan terhadap kinerja karyawan (Wardhana, dkk. 2019; Abror, 2020; Lina, 2020; Widyani, 2020). Namun, studi yang dilakukan oleh Ali K (2019) menemukan bahwa rekrutmen memiliki pengaruh tidak signifikan terhadap kinerja karyawan. Lebih lanjut studi tentang penempatan diketahui memiliki pengaruh positif dan signifikan terhadap kinerja karyawan (Hijrah, dkk. 2014; Fitria, 2017; Martini, 2017; Abror , 2020; Aldy, 2020; Febrianti, 2020; Manullang, dkk. 2020). Temuan tersebut berbeda dengan hasil penelitian yang dilakukan oleh Lussy (2018) yang mengkonfirmasi bahwa penempatan tidak berpengaruh terhadap kinerja karyawan.

Berdasar permasalahan dan terdapat kesenjangan hasil penelitian sebelumnya antara perencanaan sumber daya manusia, rekrutmen dan penempatan terhadap kinerja. Maka penelitian ini akan mengklarifikasi kesenjangan tersebut, sehingga dapat memberikan kontribusi bagi perusahaan untuk menjadi bahan pertimbangan dalam mengembangkan strategi pencapaian kinerja. Dengan demikian tujuan dari peneltian ini adalah untuk menganalisis pengaruh perencanaan sumber daya manusia, rekrutmen dan penempatan terhadap kinerja karyawan Bank Indonesia Bengkulu.

\section{Landasan Teori}

\section{Perencanaan Sumber Daya Manusia}

Menurut Nasution (2016) manajemen sumber daya manusia adalah pendekatan terhadap manajemen manusia. Pendekatan terhadap manajemen manusia didasarkan pada nilai manusia dalam hubungannya dengan organisasi. Manusia merupakan sumber daya yang penting dalam organisasi di samping itu efektivitas organisasi sangat ditentukan oleh manajemen manusia. Berbeda halnya menurut Mangkunegara (2013), mengemukakan bahwa perencanaan sumber daya manusia atau perencanaan tenaga kerja didefenisikan sebagai proses menentukan kebutuhan akan tenaga kerja dan berarti mempertemukan kebutuhan tersebut agar pelaksanaannya berintergarsi dengan rencana organisasi. Menurut Moekijat (2016), perencanaan sumber daya manusia adalah suatu proses yang berusaha menjamin bahwa jumlah dan jenis karyawan yang tepat akan tersedia pada tempat yang tepat, pada waktu yang tepat untuk waktu yang akan datang, mampu melakukan hal-hal yang diperlukan agar organisasi 
dapat terus mencapai tujuan. Selanjutnya menurut Handoko (2014), perencanaan sumber daya manusia adalah serangkaian kegiatan yang dilakukan untuk mengantisipasi permintaanpermintaan bisnis dan lingkungan pada organisasi di waktu yang akan datang dari untuk memenuhi kebutuhan-kebutuhan tenaga kerja yang ditimbulkan oleh kondisi-kondisi tertentu. Sedangkan, menurut Nawawi (2017), perencanaan SDM adalah proses menetapkan strategi untuk memperoleh, memanfaatkan, mengembangkan dan mempertahankan SDM sesuai dengan kebutuhan organisasi/perusahaan sekarang dan pengembangannya dimasa depan.

Indikator perencanaan sumber daya manusia menurut Hasibuan (2017) terdiri atas pengadaan, pengembangan, kompensasi, pemeliharaan, dan pemberhentian. Sedangkan menurut Siagian (2014), indikator perencanaan sumber daya manusia terdiri dari faktor eksternal dan internal dengan penjelasan sebagai berikut: (1) Faktor-faktor eksternal adalah berbagai hal yang pertumbuhan dan perkembangannya berada diluar kemampuan organisasi untuk mengendalikannya meliputi: situasi ekonomi, sosial budaya, politik, peraturan perundang-undangan, teknologi dan pesaing; (2) Faktor-faktor internal adalah berbagai kendala yang terdapat di dalam organisasi itu sendiri. Faktor internal meliputi: rencana strategik, anggaran, estimasi produksi dan penjualan, usaha atau kegiatan baru, dan rancangan organisasi dan tugas pekerjaan.

\section{Rekrutmen}

Menurut Mardianto (2014) rekrutmen diartikan sebagai suatu proses untuk mendapatkan calon karyawan yang memiliki kemampuan yang sesuai dengan kualifikasi dan kebutuhan suatu organisasi/perusahaan. Menurut Rivai (2013), rekrutmen adalah proses untuk mendapatkan sejumlah sumber daya manusia (karyawan) yang berkualitas untuk menduduki suatu jabatan atau pekerjaan dalam suatu perusahaan. Menurut Hasibuan (2017), Penarikan (recruitment) adalah masalah penting dalam pengadaan tenaga kerja. Jika penarikan berhasil artinya banyak pelamar yang memasukkan lamarannya, peluang untuk mendapatkan karyawan yang baik terbuka lebar, karena perusahaan dapat memilih yang terbaik diantara yang baik. Selanjutnya pengertian rekrutmen menurut Samsudin (2016) yaitu proses mendapatkan sejumlah calon tenaga kerja yang kualifaid untuk jabatan/pekerjaan tertentu dalam suatu organisasi atu perusahaan. Menurut Sudiro (2015), rekrutmen terdiri atas enam indikator yaitu proses rekrutmen, metode rekrutmen, persyaratan rekrutmen, tujuan rekrutmen, penentuan jumlah dan kualifikasi calon karyawan, dan hasil rekrutmen.

\section{Penempatan}

Menurut Ambar dan Rosida (2013) penempatan adalah suatu kebijakan yang diambil oleh pimpinan suatu instansi atau bagian kekaryawanan untuk menentukan seseorang karyawan masih tetap atau tidak ditempatkan pada suatu posisi atau jabatan tertentu berdasarkan pertimbangan keahlian, keterampilan atau kualifikasi tertentu. Menurut Hariandja (2016) penempatan kerja merupakan proses penugasan/pengisisan jabatan atau penugasan kembali pada tugas/jabatan baru atau jabatan yang berbeda. Sedangkan menurut Danang (2015), penempatan adalah penugasan kembali seorang karyawan kepada pekerjaan barunya. Penempatan (Placement) adalah tindak lanjut dari seleksi, yaitu menempatkan calon karyawan yang diterima (lulus seleksi) pada jabatan atau pekerjaan yang membutuhkannya dan sekaligus mendelegasikan authority kepada orang tersebut (Hasibuan, 2017). Penempatan adalah merupakan serangkaian langkah kegiatan yang dilaksanakan untuk memutuskan apakah tepat atau tidaknya seseorang karyawan ditempatkan pada posisi tertentu yang ada di dalam organisasi. Menurut Suwatno (2015), indikator yang dapat digunakan untuk mengukur variabel 
penempatan adalah latar belakang pendidikan, keterampilan dan pengalaman kerja, kondisi kesehatan fisik, dan usia.

\section{Kinerja}

Menurut Mangkunegara (2013), kinerja adalah hasil kerja secara kualitas dan kuantitas yang dicapai oleh seorang karyawan dalam melaksanakan tugasnya sesuai dengan tanggung jawab yang diberikannya. Kinerja adalah suatu hasil kerja yang dicapai seseorang dengan melaksanakan tugas yang dibebankan kepadanya yang didasarkan atas kecakapan, pengalaman, kesungguhan serta waktu (Hasibuan 2017). Sedangkan menurut As'ad (2016) kinerja adalah kualitas, kuantitas, waktu yang dipakai, jabatan yang dipegang, absensi, dan keselamatan dalam menjalankan pekerjaan. Dimensi mana yang penting adalah berbeda antara pekerjaan yang satu dengan pekerjaan yang lain. Menurut Robbins (2016), terdapat enam indikator kinerja yaitu kualitas, kuantitas, ketepatan waktu, efektifitas, kemandirian, dan komitmen kerja. Mangkunegara (2013) menyatakan bahwa indikator yang mempengaruhi kinerja adalah faktor kemampuan dan motivasi. Sedangkan menurut Nasution (2016), indikator kinerja terdiri atas kualitas kerja, kuantitas kerja, disiplin kerja, inisiatif dan kerjasama.

\section{Kerangka Analisis}

Perencanaan sumber daya manusia, rekrutmen dan penempatan menjadi suatu hal yang sangat penting bagi peningkatan kinerja karyawan. Sebagai alur hubungan antara variabel tersebut dalam penelitian ini dijelaskan pada gambar 1.

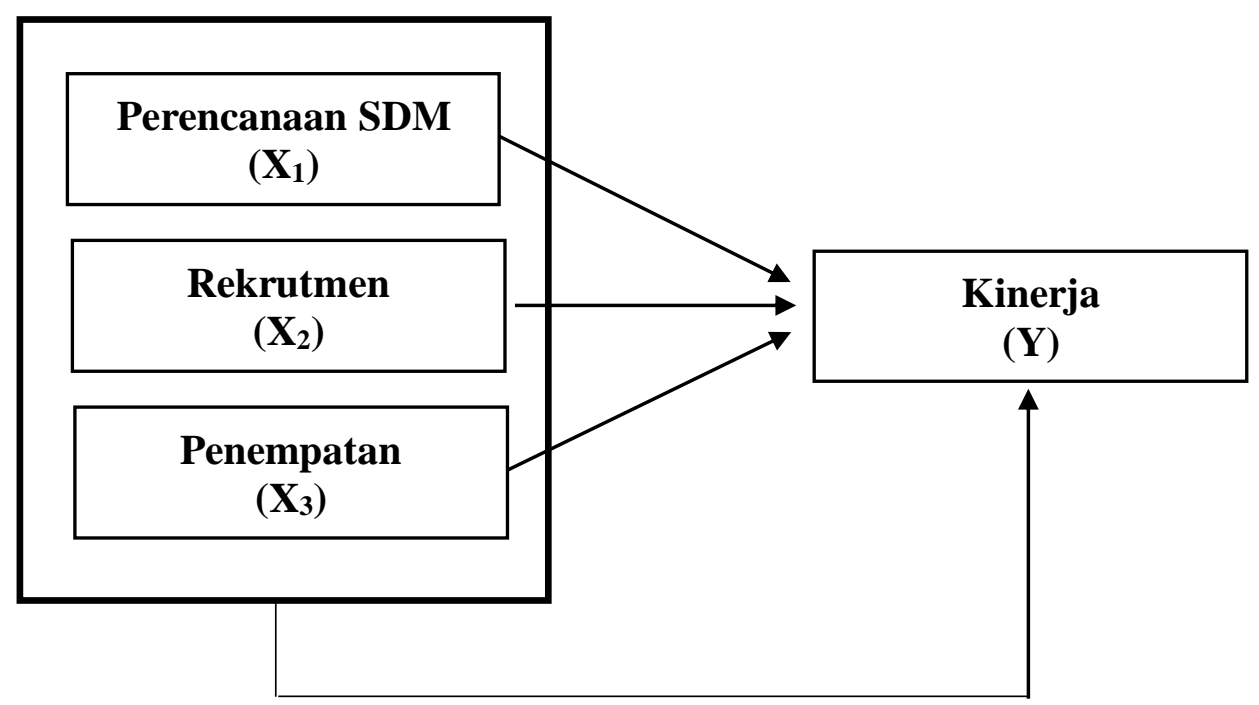

Gambar 1. Kerangka Analisis

\section{Metode Penelitian}

Metode kuantitatif digunakan dalam penelitian ini. Untuk mengetahui signifikansi pengaruh perencanaan sumber daya manusia, rekrutmen dan penempatan terhadap kinerja 48 orang karyawan tetap pada Kantor Perwakilan Bank Indonesia Provinsi Bengkulu baik secara parsial maupun secara simultan, maka dilakukan pengujian hipotesis dengan menggunakan uji parsial (uji t) dan uji simultan (uji F atau Anova). Namun sebelumnya terlebih dahulu dilakukan 
uji validitas dan reliabilitas. Uji determinasi juga dilakukan guna mengetahui seberapa besar variabel-variabel bebas mempengaruhi variabel terikat. Persamaan untuk model regresi linier berganda sebagai berikut:

Keterangan :

$$
\mathbf{Y}=\boldsymbol{\beta}_{0}+\boldsymbol{\beta}_{1} \mathbf{X}_{1}+\boldsymbol{\beta}_{2} \mathbf{X}_{2}+\boldsymbol{\beta}_{3} \mathbf{X}_{3}
$$

$\mathrm{Y}=$ Kinerja

$\mathrm{B}_{0}=$ Konstanta

$\beta_{1}=$ Standar koefisien regresi linier dari perencanaan SDM

$\beta_{2}=$ Standar koefisien regresi linier dari rekrutmen

$\beta_{3}=$ Standar koefisien regresi linier dari penempatan

$\mathrm{X}_{1}=$ Perencanaan SDM

$\mathrm{X}_{2}=$ Rekrutmen

$\mathrm{X}_{3}=$ Penempatan

\section{Hasil dan Pembahasan}

\section{Uji Validitas dan Reliabilitas}

Hasil uji validitas atas pernyataan dari seluruh indikator memiliki tingkat validitas yang sesuai dengan kriteria yang diajukan pada penelitian ini, yaitu semua indikator memiliki nilai $\mathrm{R}$-hitung $>\mathrm{R}$-tabel. Maka semua indikator yang digunakan dalam penelitian ini valid dan dapat digunakan sebagai alat penelitian. Selanjutnya dari hasil uji reliabilitas yang dilakukan dengan menggunakan program statistik SPSS maka diperoleh hasil cronbach's alpha lebih besar dari 0,60 untuk keempat variabel bebas yaitu perencanaan SDM, rekrutmen, penempatan dan kinerja. Oleh karena itu, semua variabel yang disusun dalam bentuk kuesioner memiliki kehandalan dan dapat dijadikan alat ukur.

\section{Regresi Linier Berganda}

Berdasarkan hasil penyebaran kuesioner yang dilakukan terhadap 48 orang karyawan tetap pada Kantor Perwakilan Bank Indonesia Provinsi Bengkulu, kemudian dilakukan pengolahan data menggunakan program SPSS for windows versi 16.0, maka diperoleh hasil sebagai berikut:

Tabel 1. Hasil Regresi Linier Berganda

Coefficients ${ }^{a}$

\begin{tabular}{|c|c|c|c|c|c|c|}
\hline \multirow{2}{*}{\multicolumn{2}{|c|}{ Model }} & \multicolumn{2}{|c|}{$\begin{array}{c}\text { Unstandardized } \\
\text { Coefficients }\end{array}$} & \multirow{2}{*}{$\begin{array}{c}\text { Standardized } \\
\text { Coefficients } \\
\text { Beta } \\
\end{array}$} & \multirow[b]{2}{*}{$\mathrm{t}$} & \multirow[b]{2}{*}{ Sig. } \\
\hline & & B & Std. Error & & & \\
\hline \multirow[t]{4}{*}{1} & (Constant) & 1.496 & 1.819 & & .822 & .415 \\
\hline & Perencanaan SDM & .364 & .090 & .348 & 4.032 & .000 \\
\hline & Rekrutmen & .525 & .089 & .558 & 5.900 & .000 \\
\hline & Penempatan & .710 & .032 & .716 & 6.296 & .000 \\
\hline
\end{tabular}

a. Dependent Variable: Kineria 
Berdasar hasil perhitungan pada tabel 1 yang ditulis dalam bentuk unstandardized coefficients, maka dapat dibuat persamaan regresi linear berganda yaitu:

$$
Y=1.496+0,364 X_{1}+0,525 X_{2}+0,710 X_{3}
$$

Persamaan 2 regresi linier berganda dapat dijelaskan bahwa nilai konstanta 1,496 mempunyai arti bahwa apabila variabel perencanaan $\operatorname{SDM}\left(\mathrm{X}_{1}\right)$, rekrutmen $\left(\mathrm{X}_{2}\right)$ dan penempatan $\left(\mathrm{X}_{3}\right)$ dianggap sama dengan nol maka variabel Kinerja (Y) akan tetap sebesar 1,496. Nilai koefesien regresi variabel $\mathrm{X}_{1}$ (perencanaan $\mathrm{SDM}$ ) adalah sebesar 0,364 dengan asumsi apabila $\mathrm{X}_{1}$ (perencanaan SDM) mengalami peningkatan sebesar satu-satuan maka Y (Kinerja) akan mengalami peningkatan sebesar 0,364 kali. Nilai koefesien regresi variabel $\mathrm{X}_{2}$ (rekrutmen) adalah sebesar 0,525 dengan asumsi apabila $\mathrm{X}_{2}$ (rekrutmen) mengalami kenaikan sebesar satusatuan maka Y (Kinerja) akan mengalami peningkatan sebesar 0,525 kali. Nilai koefesien regresi variabel $\mathrm{X}_{3}$ (penempatan) adalah sebesar 0,710 dengan asumsi apabila $\mathrm{X}_{3}$ (penempatan) mengalami kenaikan sebesar satu-satuan maka Y (Kinerja) akan mengalami peningkatan sebesar 0,710 kali.

\section{Koefisien Determinasi $\left(\mathbf{R}^{2}\right)$}

Koefesien Determinasi ini digunakan untuk menghitung besarnya peranan atau pengaruh perencanaan SDM, rekrutmen dan penempatan terhadap kinerja. Nilai koefisien determinasi ditentukan dengan nilai $\mathrm{R}$ square Adapun hasil output SPSS untuk koefesien determinasi seperti pada tabel 2.

Tabel 2. Koefisien Determinasi

\begin{tabular}{|l|r|r|r|r|}
\hline Model & R & R Square & \multicolumn{1}{|c|}{$\begin{array}{c}\text { Adjusted R } \\
\text { Square }\end{array}$} & $\begin{array}{c}\text { Std. Error of the } \\
\text { Estimate }\end{array}$ \\
\hline 1 & $.893^{a}$ & .797 & .783 & \multicolumn{1}{|c|}{.862} \\
\hline
\end{tabular}

a. Predictors: (Constant), Penempatan, Perencanaan SDM, Rekrutmen

Hasil perhitungan sebagaimana ditunjukkan pada tabel 2 bahwa nilai koefesien determinasi dari $R$ square yaitu sebesar 0,797. Hal ini berarti bahwa perencanaan SDM, rekrutmen dan penempatan memiliki pengaruh terhadap kinerja sebesar 79,7 \% sedangkan sisanya $(20,3 \%)$ dipengaruhi oleh faktor-faktor lainnya yang tidak diteliti dalam penelitian ini.

\section{Pengujian Hipotesis}

\section{Uji t}

Hasil perhitungan sebagaimana ditunjukkan pada tabel 1 menunjukkan nilai signifikansi variabel perencanaan SDM sebesar 0,000 lebih kecil dari 0,05, sehingga dapat disampaikan bahwa perencanaan SDM berpengaruh signifikan terhadap kinerja karyawan pada Kantor Perwakilan Bank Indonesia Provinsi Bengkulu, dengan demikian hipotesis awal yang diajukan dapat terbukti (Ha diterima). Selanjutnya, nilai signifikansi variabel rekrutmen sebesar 0,000 lebih kecil dari 0,05, sehingga dapat disampaikan bahwa rekrutmen berpengaruh signifikan terhadap kinerja karyawan pada Kantor Perwakilan Bank Indonesia Provinsi 
Bengkulu, dengan demikian hipotesis kedua yang diajukan dapat terbukti (Ha diterima). Demikian halnya dengan nilai signifikansi variabel penempatan sebesar 0,000 lebih kecil dari 0,05, sehingga dapat disimpulkan bahwa penempatan berpengaruh signifikan terhadap kinerja karyawan pada Kantor Perwakilan Bank Indonesia Provinsi Bengkulu, dengan demikian hipotesis ketiga yang diajukan dapat terbukti (Ha diterima).

\section{Uji F}

Uji F dilakukan untuk mengetahui apakah variabel bebas secara simultan memiliki pengaruh yang signifikan terhadap variabel terikat. Berdasarkan hasil uji $\mathrm{F}$ pada tabel 3 , menunjukkan signifikansi sebesar $0,000<0,05$. Karena tingkat signifikansi di bawah 0,05 dapat disampaikan bahwa variabel perencanaan SDM, rekrutmen dan penempatan berpengaruh signfikan secara bersama-sama terhadap kinerja karyawan pada Kantor Perwakilan Bank Indonesia Provinsi Bengkulu, dengan demikian hipotesis awal yang diajukan terbukti (Ha diterima).

Tabel 3. Hasil Uji F (Anova)

\begin{tabular}{|ll|r|r|r|c|r|}
\hline \multicolumn{1}{|c|}{ ANOVA $^{\mathrm{a}}$} \\
\hline 1 & Sum of Squares & \multicolumn{1}{c|}{$\mathrm{df}$} & Mean Square & $\mathrm{F}$ & \multicolumn{1}{c|}{ Sig. } \\
\hline & Regression & 128.544 & 3 & 42.848 & 57.644 & $.000^{\mathrm{b}}$ \\
& Residual & 32.706 & 44 & .743 & & \\
& Total & 161.250 & 47 & & & \\
\hline
\end{tabular}

a. Dependent Variable: Kinerja

b. Predictors: (Constant), Penempatan, Perencanaan SDM, Rekrutmen

\section{Pembahasan}

\section{Pengaruh Perencanaan SDM Terhadap Kinerja}

Hasil penelitian menunjukkan bahwa nilai regresi untuk pengaruh perencanaan SDM terhadap kinerja menunjukan nilai sebesar 0,364 atau memiliki arah regresi yang positif, Artinya semakin meningkat perencanaan SDM pada karyawan Kantor Perwakilan Bank Indonesia Provinsi Bengkulu maka kinerja juga akan meningkat. Hal ini sejalan dengan hasil uji hipotesis bahwa perencanaan SDM berpengaruh signifikan terhadap kinerja karyawan pada Kantor Perwakilan Bank Indonesia Provinsi Bengkulu karena nilai signifikan sebesar 0,000 kecil dari 0,05 . Hal ini menggambarkan dengan adanya perencanaan yang matang untuk SDM maka kinerja karyawan akan meningkat. Hasil penelitian ini sesuai dengan pendapat Nawawi (2017) bahwa perencanaan SDM adalah proses menetapkan strategi untuk memperoleh, memanfaatkan, mengembangkan dan mempertahankan SDM sesuai dengan kebutuhan organisasi/perusahaan sekarang dan pengembangannya dimasa depan. Berdasarkan pengertian perencanaan sumber daya manusia di atas, penulis sampai pada pemahaman bahwa perencanaan sumber daya manusia adalah suatu proses dalam menentukan kebutuhan tenaga kerja, baik dari internal maupun eksternal sebuah perusahaan untuk memperoleh dan menyediakan tenaga kerja yang tepat sehingga mampu mencapai tujuan perusahaan atau organisasi. Hasil penelitian ini juga selaras dengan penelitian yang dilakukan oleh Fitria (2017); Haqiqi (2017); dan Saputra, dkk. (2020). 
INOBIS: Jurnal Inovasi Bisnis dan Manajemen Indonesia

Volume 03, Nomor 02, Maret 2020

Heru Saputra, Ahmad Soleh, Ida Ayu Made Er Meytha Gayatri

\section{Pengaruh Rekrutmen Terhadap Kinerja}

Hasil penelitian menunjukkan bahwa nilai regresi untuk rekrutmen sebesar 0,525 dengan arah regresi positif, artinya semakin meningkat perhatian terhadap rekrutmen karyawan maka akan meningkatkan kinerja karyawan Kantor Perwakilan Bank Indonesia Provinsi Bengkulu. Hasil uji hipotesis untuk pengaruh rekrutmen terhadap kinerja karyawan pada Kantor Perwakilan Bank Indonesia Provinsi Bengkulu memiliki pengaruh yang signifikan, karena nilai signfikan sebesar 0,000 kecil dari 0,05. Hal ini menggambarkan dengan adanya peningkatan perhatian terhadap rekrutmen karyawan maka akan meningkatkan kinerja karyawan. Hasil penelitian ini sejalan dengan pendapat Rivai (2013), rekrutmen adalah proses untuk mendapatkan sejumlah sumber daya manusia (karyawan) yang berkualitas untuk menduduki suatu jabatan atau pekerjaan dalam suatu perusahaan. Dalam upaya mencapai tujuan perusahaan, proses rekrutmen mempunyai peran yang sangat penting karena para karyawan yang direkrut itulah nanti yang akan menggerakkan seluruh aspirasi dan merealisasikan tujuan perusahaan secara administrasi dan operasional. Kinerja yang baik dan berkualitas boleh dicapai melalui proses perekrutan karyawan yang baik dan menepati segala prosedur dan teknik rekrutmen. Karena itulah proses rekrutmen karyawan boleh dikatakan sangat berpengaruh terhadap kinerja. Hasil penelitian ini juga selaras dengan penelitian yang dilakukan oleh Wardhana, dkk (2019); Abror (2020); Lina (2020); dan Widyani (2020).

\section{Pengaruh Penempatan Terhadap Kinerja}

Hasil penelitian menunjukkan nilai regresi untuk penempatan sebesar 0,710 dengan arah regresi positif, artinya semakin tepat penempatan karyawan maka kinerja karyawan Kantor Perwakilan Bank Indonesia Provinsi Bengkulu akan semakin meningkat. Hasil uji hipotesis untuk pengaruh penempatan terhadap kinerja karyawan pada Kantor Perwakilan Bank Indonesia Provinsi Bengkulu memiliki pengaruh yang signifikan, karena nilai signfikan sebesar 0,000 kecil dari 0,05. Hal ini menggambarkan dengan adanya penempatan karyawan yang sesuai dengan keterampilan dan pengetahuannya dapat meningkatkan kinerja karyawan. Hasil penelitian ini sejalan dengan pendapat Hariandja (2016) bahwa penempatan kerja merupakan proses penugasan/pengisisan jabatan atau penugasan kembali pada tugas/jabatan baru atau jabatan yang berbeda. Untuk menempatkan karyawan pada posisinya juga harus mempertimbangkan pengetahuan seseorang mengenai pekerjaan, semakin tinggi pengalaman seseorang maka tingkat pengetahuannya dalam bekerja juga akan meningkat sehingga prestasi kerja seseorang juga akan meningkat. Keterampilan yang dimiliki oleh karyawan juga akan menentukan posisi seseorang dalam bekerja. Semakin tinggi keterampilan yang dimiliki oleh seseorang maka dalam bekerja dia akan mendapatkan promosi kejabatan yang lebih tinggi. Hasil penelitian ini juga selaras dengan penelitian yang dilakukan oleh Hijrah, dkk (2014); Fitria (2017); Martini (2017); Abror (2020); Aldy (2020); Febrianti (2020); dan Manullang dkk. (2020).

\section{Kesimpulan}

Kantor Perwakilan Bank Indonesia Provinsi Bengkulu merupakan salah satu lembaga tinggi negara. Karyawan dituntut memiliki kinerja yang tinggi dalam dalam pelaksanaan tugas dan tanggungjawanya. Perencanaan SDM, rekrutmen dan penempatan menjadi hal yang sangat penting. Berdasar hasil penelitian menunjukkan bahwa variabel perencanaan SDM, rekrutmen dan penempatan memiliki pengaruh positif dan signifikan terhadap kinerja karyawan baik 
INOBIS: Jurnal Inovasi Bisnis dan Manajemen Indonesia

Volume 03, Nomor 02, Maret 2020

Heru Saputra, Ahmad Soleh, Ida Ayu Made Er Meytha Gayatri

dilakukan secara parsial maupun simultan. Besar pengaruh ketiga variabel tersebut sebesar $79,7 \%$.

\section{Daftar Pustaka}

Abror. (2020). Pengaruh Rekrutmen dan Penempatan terhadap Kinerja Karyawan pada CV. Yen's Delight di Samarinda. eJournal Administrasi Bisnis. 8(2). 152-161.

Aldy, Hafis Laksmana. (2020). Pengaruh Penempatan Kerja terhadap Kinerja Karyawan pada Yayasan Hanifa Islamic School. Jurnal Ekonomi Efektif. 2(2). 220-225.

Ambar, Teguh Sulistiyani dan Rosidah. (2013). Manajemen Sumber Daya Manusia. Yogyakarta : Graha Ilmu.

As'ad, Moh. (2016). Seri Ilmu SDM : Psikologi Industri, Edisi Keempat. Yogyakarta : Liberty. Bohlander, George., and Snell, Scott. (2010). Principles of Human Resource. Management, 15th ed. Mason, OH: South Western - Cengage Learning.

Danang, Sunyoto. (2015). Manajemen Dan Pengembangan Sumber Daya Manusia. Yogyakarta: CAPS.

Febrianti, Reni. (2020). Pengaruh Penempatan dan Kompensasi terhadap Kinerja Karyawan pada PT Primavera International Jakarta. Jurnal Manajemen MH Thamrin. 1. 54-68.

Fitria. (2017). Pengaruh Perencanaan dan Penempatan Pegawai terhadap Kinerja Pegawai pada Badan Kepegawaian Daerah Kota Lubuk Linggau. Menara Ekonomi. III(5), 33-41.

Hafni, Layla dan Husni, Nia. (2016). Pengaruh Perencanaan Sumber Daya Manusia dan Disiplin Kerja Terhadap Kinerja Karyawan Pada PT. Federal International Finance Cabang Soekarno Hatta Pekanbaru. Jurnal Ilmiah Manajemen. 4(1), 1-10.

Handoko, Hani. (2014) Manajemen Personalia dan Sumber Daya Manusia. Yogyakarta: BPFE. Hariandja, Marihot T.E. (2016). Manajemen Sumber Daya Manusia. Jakarta: Grasindo.

Hasibuan, Malayu. (2017). Manajemen Sumber Daya Manusia, Cetakan Kesembilan. Jakarta : PT Bumi Aksara.

Haqiqi, Rizky Trisna Firman. (2017). Pengaruh Perencanaan dan Pengembangan Sumber Daya Manusia Terhadap Kinerja Karyawan PT. Permata Bahari Malindonesia. Jurnal Manajemen Bisnis. 7(1), 57-68.

Hijrah., Sjahruddin, Herman dan Heslina. (2014). Pengaruh Penempatan dan Keterlibatan Kerja terhadap Kinerja Karyawan pada PT. Bank BNI (Persero) Tbk Cabang Makassar. E-Library STIE YPBUP Bogaya. 1-14.

Lina, Roidah. (2020). Pengaruh Rekrutmen terhadap Kinerja Karyawan. Scientific Journal of Reflection: Economic, Accounting, Management and Business. 3(3). 282-290.

Mangkunegara. (2013). Manajemen Sumber Daya Manusia Perusahaan. Bandung: PT. Remaja Rosdakarya

Martini, Ni Putu Riski. (2017). Pengaruh Penempatan Sumber Daya Manusia pada Kinerja Karyawan di Pemerintah Kabupaten Badung. Jurnal Krisna: Kumpulan Riset Akuntansi. 9(1), 70-79.

Mardianto, Adi. (2014). Manajemen Rekrutmen. Jakarta: Salemba Empat.

Manullang, Ahmad Kennedy., Puspa, Tiara dan Wardini, Amalia Kusuma. (2020). Pengaruh Kompetensi dan Penempatan Kerja terhadap Kinerja Pegawai Negeri Sipil di Kabupaten Tapanuli Tengah. Makro, Jurnal Manajemen dan Kewirausahaan. 5(2). 107 119.

Moekijat. (2016). Manajemen Sumber Daya Manusia. Cetakan Kesembilan. Bandung: Mandar Maju.

Nasution, Mulia. (2016). Manajemen Personalia. Jakarta: Djambatan. 
Nawawi, Hadari. (2017). Perencanaan SDM Untuk Organisasi Profit Yang Kompetitif. Yogyakarta: UGM Press.

Rafikah. (2020). Pengaruh Perencanaan Sumber Daya Manusia (SDM) dan Kompetensi TerhadapKinerja Karyawan di Yayasan Darul Hijrah Puteri Banjarbaru. Jurnal Komunikasi Bisnis dan Manajemen. 7(1), 46-54.

Rivai, Veithzal. 2013, Manajemen Sumber Daya Manusia untuk Perusahaan dari Teori ke Praktek. Jakarta: PT. Grafindo Persada.

Robbins, Stephen P. (2016). Perilaku Organisasi Edisi 16. Jakarta: Salemba Empat.

Saputra, Redy Tri., Ratnasari, Sri Langgeng dan Tanjung Rona. (2020). Pengaruh Manajemen

Talenta, Perencanaan SDM dan Audit SDM terhadap Kinerja Karyawan. Jurnal Trias Politika. 4(1). 90-99.

Samsudin, Sadili. (2016). Manajemen Sumber Daya Manusia. Bandung: Pustaka Setia.

Sudiro, Achmad. (2015). Perencanaan Sumber Daya Manusia. Cetakan Pertama. UB Press. Malang Indonesia.

Suwatno. (2015). Manajemen Sumber Daya Manusia Dalam Organisasi Publik dan Bisnis. Bandung: Alfabeta.

Wardhana, Ananto Krisna., Nainggolan, Kaman., Lestiowati, Riris dan Fadly, Rachmat. (2019). Pengaruh Sistem Rekrutmen dan Lingkungan Kerja Terhadap Kinerja Karyawan (Studi Kasus Pada PT. Hyundai Mobil Indonesia-Pusat, Jalan Teuku Nyak Arief Simprug. Jurnal Akuntansi dan Manajemen. 16(2), 162-176.

Widyani, Anak Agung Dwi. (2020). Pengaruh Rekrutmen dan Promosi Jabatan Terhadap Kinerja Karyawan pada PT. Bank Sinarmas Cabang Denpasar. Jurnal Widya Manajemen. 2(1). 80-88. 